\title{
PENGARUH PERUBAHAN SUKU BUNGA TERHADAP PERHITUNGAN PREMI NETO TAHUNAN ASURANSI KESEHATAN INDIVIDU
}

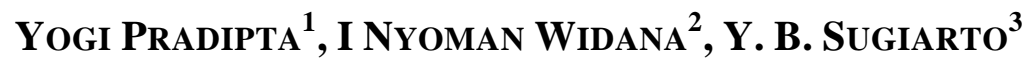 \\ 1,2,3 Jurusan Matematika FMIPA Universitas Udayana, Bukit Jimbaran-Bali \\ e-mail: 1'yogipradipta@gmail.com, ${ }^{2}$ nwidana@yahoo.co.id, ${ }^{3}$ yohanesbambang.s@gmail.com
}

\begin{abstract}
Health insurance is a type of insurance product that specifically guarantees for health care or treatment. Individual and collective health insurance are the two categories of health insurance. Estimated premiums are determined according to death rate, sex, age, level of interest and administration costs. The interest rate relied on may vary between insurers. This study used three different interest rates for the calculation of annual net premium on individual health insurance based on RP-2000 Male \& Female Combined Healthy Table and the Indonesian Mortality Table (TMI) 1999. The results indicated that an increase in interest rate causes a decrease in the premium, and vice versa. This study concludes that changes in interest rate affect the calculation of annual net premium on individual health insurance which are either renewed or not renewed.
\end{abstract}

Keywords: individual health insurance, the interest rate forecast, net premium.

\section{Pendahuluan}

Terserang penyakit merupakan resiko bagi setiap orang yang tidak mungkin dihindari. Karena ada resiko demikian akan timbul kesadaran manusia untuk bekerja sama dalam mengantisipasi atau minimal mengurangi akibat atau dampak dari resiko tersebut melalui perusahan asuransi jiwa yang salah satu produknya adalah asuransi kesehatan (Wilandari, [6]). Asuransi kesehatan dibagi menjadi dua kategori, yaitu asuransi kesehatan individu dan asuransi kesehatan kolektif. Premi yang dibayarkan pada asuransi kesehatan terbagi menjadi dua, yaitu premi neto tunggal, dan premi neto tahunan. Salah satu faktor yang memengaruhi perhitungan premi khususnya asuransi kesehatan individu adalah tingkat suku bunga. Penggunaan tingkat suku bunga yang tidak sesuai dapat menyebabkan kerugian pada salah satu pihak baik dari pihak perusahaan asuransi atau dari pihak tertanggung (Futami, [2]). Berdasarkan keadaan tersebut penulis ingin mengetahui pengaruh perubahan suku bunga terhadap perhitungan premi neto tahunan asuransi kesehatan individu berdasarkan Tabel RP-2000 Male \& Female Combined Healthy (Heidrich, [4]), dan Tabel Mortalitas Indonesia (TMI) 1999 (Ayulina, [1]) baik premi neto tahunan yang tidak diperbaharui maupun

\footnotetext{
${ }^{1}$ Mahasiswa Jurusan Matematika FMIPA Universitas Udayana

${ }^{2,3}$ Staf Pengajar Jurusan Matematika FMIPA Universitas Udayana
} 
yang diperbaharui. Beberapa simbol komutasi yang digunakan untuk mempermudah perhitungan adalah:

$$
\begin{aligned}
v & =\frac{1}{1+i}, \\
P_{x} & =\frac{l_{x+1}}{l_{x}}, \\
D_{x} & =v^{x} l_{x}, \\
N_{x} & =\sum_{i=0}^{\infty} D_{x+i}, \\
\bar{D}_{x} & =v^{x+\frac{1}{2}} l_{x}, \\
C_{x} & =v^{x+1} d_{x}, \\
M_{x} & =\sum_{i=0}^{\infty} C_{x+i} .
\end{aligned}
$$

Bentuk asuransi kesehatan merupakan kontrak khusus selama $n$ tahun, dan jika premi yang digunakan adalah premi neto tahunan, maka pembayaran preminya dapat dibagi menjadi dua, yaitu premi yang diperbaharui dan tidak diperbaharui (Futami, [3]). Misal usia tertanggung $x$ tahun, apabila selama 1 tahun ini kemungkinan dirawat di rumah sakit adalah $q_{x}^{s h}$, rata-rata jumlah hari perawatan rumah sakit $T^{s h}$ dan memperoleh benefit harian di rumah sakit sebesar 1 satuan, 1 tahun kemudian kemungkinan dirawat di rumah sakit adalah $q_{x+1}^{s h}$, kemungkinan hidup adalah ${ }_{1} P_{x}$, dan rata-rata jumlah hari perawatan rumah sakit $T^{\text {sh }}$ dan memperoleh benefit harian di rumah sakit sebesar 1 satuan, dan seterusnya sampai jangka waktu yang dikehendaki, misal $n$ tahun (Futami, [3]). Maka dengan menggunakan persamaan dasar, besar premi neto tunggalnya adalah:

$$
\begin{gathered}
P=v^{\frac{1}{2}} q_{x}^{s h} T^{s h}+v^{1+\frac{1}{2}}{ }_{1} P_{x} q_{x+1}^{s h} T^{s h}+v^{2+\frac{1}{2}}{ }_{2} P_{x} q_{x+2}^{s h} T^{s h}+\cdots \\
+v^{(n+1)+\frac{1}{2}}{ }_{n-1} P_{x} q_{x+(n-1)}^{s h} T^{s h} \\
P=T^{s h} \sum_{t=0}^{n-1} v^{t+\frac{1}{2}}{ }_{t} P_{x} q_{x+t}^{s h}
\end{gathered}
$$

Jika preminya adalah tahunan, maka premi neto tahunan pada asuransi kesehatannya adalah:

$$
\begin{aligned}
P \ddot{a}_{x: n\rceil} & =T^{s h} \sum_{t=0}^{n-1} v^{t+\frac{1}{2}}{ }_{t} P_{x} q_{x+t}^{s h} \\
P & =\frac{T^{s h} \sum_{t=0}^{n-1} v^{t+\frac{1}{2}} \frac{l_{x+t}}{l_{x}} q_{x+t}^{s h}}{\frac{N_{x}-N_{x}+n}{D_{x}}} \\
& =\frac{T^{s h} \sum_{t=0}^{n-1} \bar{D}_{x+t} q_{x+t}^{s h}}{N_{x}-N_{x+n}}
\end{aligned}
$$

\section{Metode Penelitian}

Penelitian yang dilakukan merupakan analisis data, yaitu melakukan perhitungan premi neto tahunan pada asuransi kesehatan individu baik yang tidak diperbaharui maupun yang diperbaharui dengan tiga tingkat suku bunga yang berbeda dengan sumber data sekunder yang diperoleh dari berbagai sumber buku 
yang berkaitan dengan asuransi kesehatan individu dan jenis data yang digunakan adalah data kuantitatif yang diperoleh berdasarkan Tabel RP-2000 Male \& Female Combined Healthy, dan Tabel Mortalitas Indonesia (TMI) 1999 di mana pengolahan sebagian data dilakukan dengan menggunakan software Microsoft Excel 2007.

\section{Hasil dan Pembahasan}

\section{Simulasi}

Sebuah keluarga terdiri dari ayah usia 40 tahun, ibu usia 36 tahun, dan 1 anak laki-laki usia 9 tahun membeli polis asuransi kesehatan selama 20 tahun dengan santunan Rp350.000,00 per hari untuk biaya rawat inap dan Rp100.000,00 per hari untuk biaya kunjungan dokter, rata-rata jumlah hari perawatan rumah sakit maksimal 180 hari serta Rp5.000.000,00 untuk biaya perawatan per periode per tahun.

Pada simulasi akan dihitung premi neto tahunan dengan tiga tingkat suku bunga yang berbeda menggunakan persamaan (9) dengan terlebih dahulu membuat Tabel Komutasi untuk mengetahui nilai-nilai $D_{x}, N_{x}$, dan $\bar{D}_{x}$ dengan menggunakan persamaan (3), (4), dan (5) dan memperlihatkan unsur nilai $i$ menggunakan persamaan (1).

1. Perhitungan Premi Neto Tahunan yang Tidak Diperbaharui

Berdasarkan persamaan (9) akan dilakukan perhitungan premi neto tahunan yang tidak diperbaharui dengan suku bunga $(i)=6 \%,(i)=8 \%$ dan $(i)=$ 10\%. Adapun hasil perhitungan selengkapnya dapat dilihat pada Tabel 1.

Tabel 1. Premi Neto Tahunan yang Tidak Diperbaharui

\begin{tabular}{|c|c|c|c|c|c|}
\hline \multirow{2}{*}{$\begin{array}{c}\text { Suku } \\
\text { Bunga } \\
(\boldsymbol{i})\end{array}$} & $\begin{array}{c}\text { Premi Ayah } \\
\left(\boldsymbol{P}_{\mathbf{1}}\right)\end{array}$ & $\begin{array}{c}\text { Premi Ibu } \\
\left(\boldsymbol{P}_{\mathbf{2}}\right)\end{array}$ & $\begin{array}{c}\text { Premi } \\
\text { Anak }\left(\boldsymbol{P}_{\mathbf{3}}\right)\end{array}$ & $\begin{array}{c}\text { Total Premi } \\
\text { Neto } \\
\text { Tahunan } \\
\left(\boldsymbol{P}_{\boldsymbol{t}}\right)\end{array}$ & $\begin{array}{c}\text { Total } \\
\text { Akumulasi } \\
\text { Premi } \\
\left(\boldsymbol{P}_{\boldsymbol{n}}\right)\end{array}$ \\
\hline $6 \%$ & $\mathrm{Rp} 179.038,00$ & $\mathrm{Rp} 91.927,00$ & $\mathrm{Rp} 24.145,00$ & $\mathrm{Rp} 295.110,00$ & $\mathrm{Rp} 5.902 .200,00$ \\
\hline $8 \%$ & $\mathrm{Rp} 168.058,00$ & $\mathrm{Rp} 86.408,00$ & $\mathrm{Rp} 23.389,00$ & $\mathrm{Rp} 277.855,00$ & $\mathrm{Rp} 5.557 .100,00$ \\
\hline $10 \%$ & $\mathrm{Rp} 158.249,00$ & $\mathrm{Rp} 81.419,00$ & $\mathrm{Rp} 22.682,00$ & $\mathrm{Rp} 262.350,00$ & $\mathrm{Rp} 5.247 .000,00$ \\
\hline
\end{tabular}

Berdasarkan Tabel 1 diperlihatkan bahwa total premi neto tahunan yang tidak diperbaharui dan total akumulasi premi selama kontrak polis yang harus dibayar oleh sebuah keluarga dengan tiga tingkat suku bunga yang berbeda antara lain:

1) Dengan suku bunga $(i)=6 \%$ diperoleh premi neto tahunan sebesar Rp295.110,00, sehingga total akumulasi premi selama kontrak polis adalah Rp5.902.200,00. 
2) Dengan suku bunga $(i)=8 \%$ diperoleh premi neto tahunan sebesar Rp277.855,00, sehingga total akumulasi premi selama kontrak polis adalah Rp5.557.100,00.

3) Untuk suku bunga $(i)=10 \%$ diperoleh premi neto tahunan sebesar Rp262.350,00, sehingga total akumulasi premi selama kontrak polis adalah Rp5.247.000,00.

Dari data hasil perhitungan premi neto tahunan yang tidak diperbaharui diperlihatkan bahwa telah terjadi penurunan nilai premi selama kontrak polis yang selengkapnya dapat dilihat pada Tabel 2.

Tabel 2. Penurunan Nilai Premi Neto Tahunan yang Tidak Diperbaharui

\begin{tabular}{|l|c|c|}
\hline \multicolumn{1}{|c|}{ Suku Bunga $(\boldsymbol{i})$} & Penurunan Nilai Premi & Persentase (\%) \\
\hline $6 \% \rightarrow 8 \%$ & $\mathrm{Rp} 345.100,00$ & $5,85 \%$ \\
\hline $8 \% \rightarrow 10 \%$ & $\mathrm{Rp} 310.100,00$ & $5,58 \%$ \\
\hline
\end{tabular}

Adapun rincian dari Tabel 2, dijabarkan sebagai berikut:

1) Dengan kenaikan tingkat suku bunga (i) dari $6 \%$ menjadi $8 \%$ menyebabkan terjadinya penurunan nilai premi sebesar Rp345.100,00 atau penurunan sebesar 5,85\%.

2) Dengan kenaikan tingkat suku bunga (i) dari $8 \%$ menjadi $10 \%$ menyebabkan terjadinya penurunan nilai premi sebesar Rp310.100,00 atau penurunan sebesar $5,58 \%$.

2. Perhitungan Premi Neto Tahunan yang Diperbaharui

Berdasarkan persamaan (9) akan dilakukan perhitungan premi neto tahunan yang diperbaharui dengan suku bunga $(i)=6 \%,(i)=8 \%$ dan $(i)=10 \%$. Adapun hasil perhitungan selengkapnya dapat dilihat pada Tabel 3.

Tabel 3. Premi Neto Tahunan yang Diperbaharui

\begin{tabular}{|c|c|c|c|c|}
\hline \multirow{2}{*}{$\begin{array}{c}\text { Suku } \\
\text { Bunga }(\boldsymbol{i})\end{array}$} & Premi Ayah $\left(\boldsymbol{P}_{\mathbf{1}}\right)$ & $\begin{array}{c}\text { Premi Ibu } \\
\left(\boldsymbol{P}_{\mathbf{2}}\right)\end{array}$ & Premi Anak $\left(\boldsymbol{P}_{\mathbf{3}}\right)$ & $\begin{array}{c}\text { Total } \\
\text { Akumulasi } \\
\text { Premi } \\
\left(\boldsymbol{P}_{\boldsymbol{n}}\right)\end{array}$ \\
\hline $6 \%$ & $\mathrm{Rp} 4.339 .080,00$ & $\mathrm{Rp} 2.185 .411,00$ & $\mathrm{Rp} 518.641,00$ & $\mathrm{Rp} 7.043 .132,00$ \\
\hline $8 \%$ & $\mathrm{Rp} 4.298 .715,00$ & $\mathrm{Rp} 2.165 .081,00$ & $\mathrm{Rp} 513.817,00$ & $\mathrm{Rp} 6.977 .613,00$ \\
\hline $10 \%$ & $\mathrm{Rp} 4.259 .457,00$ & $\mathrm{Rp} 2.145 .308,00$ & $\mathrm{Rp} 509.124,00$ & $\mathrm{Rp} 6.913 .889,00$ \\
\hline
\end{tabular}

Berdasarkan Tabel 3, diperlihatkan bahwa total premi neto tahunan yang diperbaharui dan total akumulasi premi selama kontrak polis yang harus dibayar oleh sebuah keluarga dengan tiga tingkat suku bunga yang berbeda antara lain:

1) Dengan suku bunga $(i)=6 \%$ diperoleh premi neto tahunan di tahun pertama sebesar Rp150.522,00 dan selanjutnya terjadi kenaikan sampai 
tahun terakhir kontrak polis sesuai dengan pertambahan usia, sehingga total akumulasi premi selama kontrak polis adalah Rp7.043.132,00.

2) Dengan suku bunga $(i)=8 \%$ diperoleh premi neto tahunan di tahun pertama sebesar Rp149.122,00, dan selanjutnya terjadi kenaikan sampai tahun terakhir kontrak polis sesuai dengan pertambahan usia, sehingga total akumulasi premi selama kontrak polis adalah Rp6.977.613,00.

3) Untuk suku bunga $(i)=10 \%$ diperoleh premi neto tahunan di tahun pertama sebesar Rp147.760,00, dan selanjutnya terjadi kenaikan sampai tahun terakhir kontrak polis sesuai dengan pertambahan usia, sehingga total akumulasi premi selama kontrak polis adalah Rp6.913.889,00.

Dari data hasil perhitungan premi neto tahunan yang diperbaharui diperlihatkan bahwa telah terjadi penurunan nilai premi selama kontrak polis yang selengkapnya dapat dilihat pada Tabel 4.

Tabel 4. Penurunan Nilai Premi Neto Tahunan yang Diperbaharui

\begin{tabular}{|l|c|c|}
\hline Suku Bunga $(\boldsymbol{i})$ & Penurunan Nilai Premi & Persentase (\%) \\
\hline $6 \% \rightarrow 8 \%$ & Rp65.519,00 & $0,93 \%$ \\
\hline $8 \% \rightarrow 10 \%$ & Rp63.724,00 & $0,91 \%$ \\
\hline
\end{tabular}

Adapun rincian dari Tabel 4 dijabarkan sebagai berikut:

1) Dengan kenaikan tingkat suku bunga (i) dari $6 \%$ menjadi $8 \%$ menyebabkan terjadinya penurunan nilai premi sebesar Rp65.519,00 atau penurunan sebesar $0,93 \%$.

2) Dengan kenaikan tingkat suku bunga (i) dari $8 \%$ menjadi $10 \%$ menyebabkan terjadinya penurunan nilai premi sebesar Rp63.724,00 atau penurunan sebesar $0.91 \%$.

\section{Kesimpulan}

Berdasarkan hasil dan pembahasan pada skripsi ini, maka disimpulkan bahwa perubahan tingkat suku bunga berpengaruh terhadap perhitungan premi neto tahunan. Dari hasil simulasi untuk total akumulasi premi yang tidak diperbaharui, kenaikan tingkat suku bunga sebesar $2 \%$ menyebabkan penurunan nilai premi sebesar 5,85\% dan 5,58\% sedangkan yang diperbaharui menyebabkan penurunan nilai premi sebesar $0,93 \%$ dan $0,91 \%$. Dengan kata lain pengaruh perubahan tingkat suku bunga berbanding terbalik terhadap perhitungan premi neto tahunan pada asuransi kesehatan individu yang artinya apabila terjadi kenaikan tingkat suku bunga akan menyebabkan terjadinya penurunan nilai premi begitu juga sebaliknya. 


\section{Daftar Pustaka}

[1] Ayulina, S. 2011. Perhitungan Premi Tahunan pada Asuransi Joint Life dan Penerapannya: Jurnal Matematika FMIPA UNY. Jogjakarta.

[2] Futami, T. 1993. Matematika Asuransi Jiwa bagian I. Diterjemahkan oleh: Gatot Herliyanto. The Kyoei Life Insurance. Tokyo.

[3] Futami, T. 1994. Matematika Asuransi Jiwa bagian II. Diterjemahkan oleh: Gatot Herliyanto. The Kyoei Life Insurance. Tokyo.

[4] Heidrich, G. 2005. Society of Actuaries (SOA) the RP-2000 Mortality Tables. http://www.soa.org/Files/Research/Exp-Study/rp00_mortalitytables.pdf. Diakses 4 Maret 2013.

[5] Murti, B. 1999. Dasar - dasar Asuransi Kesehatan: Kanisius. Jakarta http://www.bukabuku.com/browse/bookdetail/17810/dasar-dasar-asuransikesehatan. html. Diakses 3 Maret 2013

[6] Wilandari, Y. 2007. Asuransi Kesehatan Individu Perawatan Rumah Sakit: Jurnal Matematika FMIPA UNDIP. Semarang. 